\title{
DIVERSIONARY MEASURES AS A RESPONSCE OF SOCIETY TO JUVENILE CRIME IN CROATIA AND SERBIA
}

\author{
UDK: 343.91 \\ Primljeno: veljača 2017. \\ Pregledni rad
}

In every society there are individuals or organized groups who openly or covertly violate social norms that prescribe what behavior patterns. The danger of such actions is reflected in the presence of negative tendencies in the field of further social disorganization. It is known that often the criminality of juveniles become known only when it is necessary to apply repressive sanctions that include a number of limitations. Given the fact that the sentence was dominated as a criminal sanction social reaction to crime youth was purely punitive character. There for, the same types of punsihment are applied on juveniles with certain restrictions relating to the lenient punishment and much more liberal regime of imprisonment.

In such a situation society failed to achieve a more serious influence on the improvement of the status of minors and their full integration into their courses. Further development of the social and legal awareness contributed to the discovery of new forms of no / penal response. In this regard, diversion measures represent the first and right step on the road to improving juvenile offenders committed offenses in particular the fulfillment of certain conditions. The overall trends of harmonization of domestic legislation with comparative and international and regional, mostly European instruments, countries of ex-Yugoslavia incorporated in their legislation for the imposition of diversionary measures. Taking into account the planned scope of work the authors have chosen Croatia and Serbia, which are each in their own way, first spelled out, and then with great difficulty started with sporadic use of diversionary measures.

Key words: society, juveniles, diversion measures, reintegration, treatment, settlement with the victim

\section{INTRODUCTION}

In the process of producing young people a society is most responsible for their development. However, even the most organized society, a certain percentage of young people are identified first deviant and later delinquent and criminal behavior. 
In a situation where preventive activities of all actors in society did not respond to the task we are facing the that we should act effectively repressive and instead causes eliminate its consequences. It is necessary to run a repressive mechanism full of restrictions wich takes away the opportunity for minors to once again attempt to improve them self without conducting correctional or resocial treatment.

In societies with a long tradition of respect for human rights specifically take into account the provision of proper development of young people. To this end, developed a wide range of different programs to work with minors who are still, on the line of deviant behavior as a lobby to enter the zone of delinquent and criminal. Contribution to this relation to juveniles undoubtedly gives the existence and operation of a wide range of volunteers in cooperation with the organs of formal social control operate different types of treatment programs. Just to remind that in Australia, the United States, Germany, France, the United Kingdom are applying parapenal program for a long and activities that resocially affects the formation of healthy personality aware of environment in which they live and the negative effects of their own actions.

In accordance with the tendencies of convergence of national legislation with European Union Member States, Croatia, Serbia and other countries of former Yugoslavia, have started with the basic reforming of its own laws about minors. If we ignore the aspects of family law status of the juveniles come to the field of criminal law as a last line of defense of society from crime. The first step in adjusting the internal parallel legislation has been made with the adoption of the special law on the criminal liability of minors. In this respect, Croatia has made a big step forward by adopting the Law on Juvenile Courts from in 1997. in which they placed the material, process and made provisions governing criminal and legal status of minors. Along with the advancement in the field of working with juvenile delinquents the new Law on Juvenile Courts in Croatia 2011th year. On the other hand, Serbia is much later (2005.) Premiere brought a special Law on Juvenile Offenders and Criminal Protection of Juveniles modeled on the German juvenile criminal law.

In addition to a general contribution in improving and adapting the internal legislation of the European Union Member States, Croatia and Serbia have introduced a premiere for parole delay prosecution of minors accompanied by the imposition and use of diversionary measures. Although there are differences in the name of these measures, as well as some of the details concerning their physical, procedural and executive aspects of meaning and principle underlying the existence and application of the same. Specifically, the tendency to replace with a clean criminal sanctions parapenalnim and the diversion measures in juvenile criminal law is aimed at attracting wider community in the struggle for "healing" criminally infected members of the juvenile population. Therefore, we believe that the diversion measures, primarily because of their unpopular calls should be replaced by the term social measures which in fact they really should be. The key fact is that the society instead produce healthy juvenile crime and what is best placed 
Ivan Joksić i Jelena Matijašević Obradović: Diversionary measures as a responsce of society to juvenile.. Zbornik radova Pravnog fakulteta u Splitu, god. 54, 4/2017., str. 887.- 901.

to actively participate in its improvement through the implementation of measures that are non-repressive character. Among other advantages, the application of these measures to avoid stigmatization and actively contribute to better social readapting themselves minor in social and legal framework of acceptable behavior.

\section{SPECIFICS OF DIVERSIONARY MEASURES IN CROATIA}

Croatia has almost two decades ago passed the Law on Juvenile Courts (National newspaper 111/97) which provides the possibility of something different responses to juvenile crime. The next decade in Croatia, the new Law on Juvenile Courts (National newspaper 84/11 and 143/12) which eliminates shortcomings of previous and also further refine the status of a minor criminal matters. A significant step forward in the matter of legal regulation on the execution of criminal sanctions for juveniles ${ }^{1}$ is the adoption of a special Law on Execution of Sanctions minors for crimes and misdemeanors (National newspaper 153/09).

When considering the criminal status of minors in Croatia, in light of the recent law on juvenile courts, it is necessary to indicate the presence of certain tendencies that affect the application of the system of diversion measures. The main point is the introduction of simplified, informal and fast-track procedures in criminal proceedings against juveniles. This results in limit or even abandon certain procedural rights and guarantees that juveniles in the criminal proceedings against Adults on respect.With increased interest in human rights, especially the rights of accused persons in criminal proceedings, the penetration of the idea that juvenile defendants in criminal proceedings, which leads to them, should recognize some basic procedural rights that would not have come at a disadvantage compared to the adult criminal offenders part (Caric and Kustura, 2010, p. 780). On the other hand, when we consider the issue of human rights it is necessary to stick to wellknown principles: 1) human rights are inherent character 2) there are more important and less important human rights 3 ) cataloging human rights is never final, but the constant upward movement , 4) the division of human rights in accordance with the time of their verification in international instruments (the generation of human rights) etc. (Dimitrijevic, Paunovic, Djeric, 1997, pp. 26, 175).

The dominance of the sentence, as the core of criminal sanctions, has not largely achieved results in reducing juvenile crime and repairing the consequences of which he produced for all of society. Therefore, along with the humanization of society is built around the multi-party democracy, the promotion and protection of human rights of all its members, introduced in criminal proceedings against juveniles new

\footnotetext{
1 New Law on Juvenile Courts, contains the entire juvenile matters, ie, financial, procedural and excecutive provisions. However, the prevailing opinion is that the execution of criminal sanctions for juveniles should be regulated by special legal act. Criminal-political motivation or justification for legislation that would regulate the matter of execution of criminal sanctions against minors, consists in the fact that the enforcement proceedings and any necessary actions related in the same track, are precisely regulated in former legislation (Cizmek, 2013).
} 
processing capabilities through the Institute of conditional or qualifying opportunity in criminal prosecutions that followed the imposition and use of diversionary measures (special obligations). When we talk about the opportunity of prosecution can distinguish two types of opportunity:

Unconditional opportunism applies when the juvenile is first reported and it is a less severe offense that is of excessive character, situational and conditional elements without arrogance and violence, and to a minor offense is critical (Cvjetko, 2006, p. 44). In this regard, in Article 71 Paragraph 1, Law on Juvenile Courts provides: " For a criminal offense which carries a prison sentence of up to five years or a fine Attorney General may decide not to initiate criminal proceedings, although there is a reasonable suspicion that the juvenile committed the offense if it considers that it would not be expedient to take proceedings against a minor given the nature of the offense and the circumstances in which the offense was committed, the former life of the juvenile and his personal characteristics. In order to establish these facts, the public prosecutor may request notification of parents or guardians minor, other persons and institutions, and may request that information be gathered adviser in the state prosecutor's office ... ". In paragraph 2 the same article provides for the following option: "When the juvenile is reported for several offenses, but it is useful to him impose juvenile sanctions for one because the institution of proceedings for other offenses would not significantly affect the selection of juvenile sanctions, the public prosecutor may decide that there is no basis for criminal proceedings for the other offenses. This decision of the public prosecutor may bring only in relation to criminal offenses punishable by fines or imprisonment of up to five years " In terms of the type of offenses for which the state prosecutor decided to apply the principle of appropriateness are often concerned property crimes (larceny and theft), the offense of Drug Abuse (Caric, 2006, p. 11). In addition, the attorney general shall notify, with reasons, Centre for Social work (Welfare) and damaged property to its claim in a lawsuit.

Conditional opportunism exists when the public prosecutor, on the basis of previously completed requirements for the application of the principle of opportunity, can a decision not to prosecute minor conditional willingness to perform some special obligations under Article 10 Law on Juvenile Courts. "This kind of opportunity may also be applied to a juvenile who is in criminal restitution. So the Attorney General to apply conditional opportunism if the minor has previously addressed the application of regulations based on the unconditional opportunity or the juvenile has previously successfully completed a special responsibility, including for example, repair the damage for the offense of theft (Article 64, Law on Juvenile Courts), or if the ongoing educational measure of intensified care and supervision. An important criterion in this case that a minor has a relatively orderly family circumstances"(Cvjetko, 2006, p. 44).

The State Prosecutor may, if he gain the conditions for the application of the principle of opportunity, his decision not to prosecute a juvenile offender readiness condition (Article 72, Law on Juvenile Courts): 
a) to apologize to the injured party (within the meaning of Article 10, paragraph 2 , item 1)

b) according to their possibilities of repair damage caused offense (within the meaning of Article 10, paragraph 2, item 2)

c) participate in the mediation process through the court settlement (within the limits of Article 10, paragraph 5, and 9);

d) participate in the work of humanitarian organizations or activities of community or ecological importance (in terms of Article 10, paragraph 2, item 8)

e) with the consent of the legal representative of minor's undergo treatment for drug addiction or another (in the sense of Article 10, paragraph 2, item 10)

f) participate in individual or group psychosocial treatment counseling for young people (in the sense of Article 10, paragraph 2, item 11)

g) to check for knowledge of traffic regulations in the competent institution for training of drivers (in the sense of Article 10, paragraph 2, item 14)

h) other liabilities that are appropriate given the gravity of the offense and the personal and family situation of minors (under Article 10, paragraph 2, item 16).

In accordance with the powers of the attorney general, applying the principle of conditional opportunity of prosecution, may refer the juvenile to the fulfillment of specific obligations which, although treated as a sanction for its content and effect of the category of alternative measures of minors. When choosing any of the listed special obligations, the court must take into account the willingness of the juvenile to cooperate in fulfilling them, and their adaptation to it and the conditions in which they live. Imposed obligations may not exceed one year. The court ordered obligations can be subsequently modified, and / or partially or completely abolished (Joksic, 2010, p. 162).

Recognizing the importance of conditional delay of prosecution, which could folow the imposition and enforcement of specific obligations itemized in Croatia 2000th. The project started out of court settlement between the juvenile and the injured crime. Croatia took this model from the Austrian model of settlement out of court (ATA Aussergerichttlicher Tatausgleich) and the German model the bargaining between the perpetrator and the victim of crime (TOA-toeter-OpferAusgleich). It is implemented in three Croatian cities (Zagreb, Osijek and Split) on the basis of an action project that lasted five years, and in collaboration with the Ministry of Health and Social Work of the Republic of Croatia, the State Prosecution of the Republic of Croatia, Education and Rehabilitation Sciences, University of Zagreb and the "Neustrat" of Graz in Austria. The legal basis for the conduct of the project is contained in the possibilities of implementation of court settlement in the preparatory proceedings for juvenile and young adult offenders. Application of the settlement is carried out in accordance with the legal possibilities related to the application of a special obligation to juveniles who have committed to their capacities repair or compensate the damage caused offense (within the meaning of Article 10, paragraph 2, item 2, Law on Juvenile Courts). 
According to participants in this project, "the basic idea and out of court settlement to the conflict that exists between two or more parties, which is the perpetration of the crime, comes back to the participants and with the help of a professional mediator resolved. The assumption is that the person who committed the offense should take responsibility for the committed offense and be willing to meet with the injured and with the possibilities and as mutually agreed to repair or compensate for the damage. It should be clear that the court settlement is not equivalent material compensation, but in the field of criminal law openly where combatants actively participate in reducing tangible and intangible consequences of the offense. The goal of a successful agreement acceptable to both sides, which is a good basis for peaceful co-existence in the future and prevent recidivism. Although a settlement out of court, the role of the judiciary / public prosecution / court is extremely important, since it makes a decision on criminal cases will be referred to the out of court settlement and the decision on whether to dismiss the proceedings after the criminal charges or not. Cooperation and judicial services for out of court settlement is crucial because it is a shared work and shared responsibility and the need for continued and close cooperation for the benefit of the parties "(KolerTrbovic and Gmaz-Luski, 2006, pp. 936-937).

Basic requirements for the application of the out of court settlement (Cvjetko, 2003, pp. 59-60): a high degree of certainty that the juvenile committed the offense; it is a criminal offense punishable by a fine or imprisonment of up to five years; must not be carried on trivial offense, under Article 28, Criminal Code of the Republic of Croatia; voluntary consent of the minor to participate in a non-judicial settlement; voluntary consent of the victim to participate in a non-judicial settlement; take part in the proceedings and juveniles who have committed crimes (recurring); decisions on the application out of court settlement is the exclusive competence of the State Prosecutor, which, among other things, decide on whether the settlement is successful.

Despite the obligation meeting the above requirements, the implementation of court settlement it is done through the implementation of several key principles (Koler-Trbovic and Gmaz-Luski, 2006, p. 939): voluntary participation, or through the free will of the parties (the victim and the suspect) to participate in the mediation of repair or compensation; lack of pre-mediation superior results because only the injured and the suspect in a joint meeting and discussion with management agents, active and responsible decisions about the appropriateness and fairness of the type and manner of compensation; qualifications of the mediator guarantee the effectiveness of the model and provides the desired quality of implementation; clear concept allows you to set standards and monitor their compliance and evaluation of all aspects of the implementation and results; the adequacy of the proposed cases, the starting point for the implementation of the model.

It is important to point out that the minor does not require recognition of the crime. He must be prepared to deal with the victim (injured), in order to achieve its financial and emotional interests. Damage compensation is not a mandatory 
requirement for the successful implementation of medijatornog procedure. The main objective of the settlement out of court settlement by both parties (the juvenile and the victim), and the establishment of social peace. Accordingly, the award of damages is often not commensurate with the real damage, it may have a symbolic character (Nikolic and Joksic, 2011, p. 196).

The results achieved by this project have confirmed the validity of consensual resolution of criminal conflict resulted from the crime by juveniles. The needs of victims are specifically taken into account by conditional negotiation amount and manner of compensation of damage. A little later (2006.), The Government adopted a National Plan of Action for the rights and interests of children since 2006. by 2012. In order to animate the general public on the need for reducing the possibility of corporal punishment provided for the following activities: public display of a ban on corporal punishment, posting messages that warn of the prohibition of corporal punishment in the consumer product which is intended for adults and children as well as organizing meetings, conferences and round tables, distribution of posters and leaflets, raising public awareness through the media (Vidovic, 2008, p. 318).

In our opinion, the project out of court settlement has all the elements and attributes of civil proceedings in which the participants achieved an appropriate agreement or settlement representing their own interests. The interest of the minor is to avoid conducting a formal criminal proceedings which followed the imposition of a register of criminal sanctions, and the interest of the injured party is to achieve best possible material gratification-compensation and emotionally satisfying crimeconfession by a juvenile and his apology (Nikolic and Joksic, 2011, p. 196).

Updating of juvenile criminal law in Croatia, in part related to the implementation of diverse measures, under the direct influence of international and regional instruments governing criminal and legal status of minors. Viewed through the prism of taking on new legislation in Croatia, starting as far back as in 1997. year, to the new Law on Juvenile Courts since 2011. year, it is necessary to point out that there are numerous problems of substantive law and procedural law of nature. In this sense, Professor Caric said: "In considering the implementation of international standards in the Croatian juvenile criminal law is an issue of general orientations of juvenile justice, whether it represented exclusively or predominantly punitive and repressive elements that draw their origin from the general criminal justice system, or the prevailing educational and protective elements that make it progressively and significantly different to the general criminal law "(Caric, 2006, p. 3).

In legal terms, the Croatian juvenile criminal law is incorporated in its provisions on the imposition of special duties (Article 10 of the Law on Juvenile Courts). The position of these measures and their relationship to criminal sanctions measurable through their level of compliance with current trends prevailing in the international and European instruments roof of minors. Procedural provisions concerning the application of the principle of conditional opportunity, followed by the imposition of the registry offered special obligations, moving in line with implementation of the principle of legality and opportunity taking into account primarily the 
interests of the juvenile crime victim and the community as a whole. However, the biggest problems occurs in the field of application possibilities conditional delay prosecution that followed the imposition and implementation of some of the special obligations. Aware of the difficulties that occurs in the field of execution of special obligations in Croatia are the steps taken in the field of decision-making subordinate laws governing the use of certain liabilities. Shortly after the adoption of the current Law on Juvenile Courts shall be separate Regulations which further regulate the jurisdiction and procedure of execution of corrective measures and specific commitments (National newspaper 141/11 and 21/12). Under the general provisions (Article 18 of the Regulation) prescribes the method to perform specific obligations, such as the head of the educational measures with a minor and the parents / guardians and the young adults, in a written mutual agreement on a special form provided in the attached Ordinance, the methods to be specifically imposed special obligations.

The analysis of policy imposing special obligations in Croatia, we can observe a relatively high level of participation (29.3\%) of the total number of pronounced educational measures. If we take the statistics for the imposition of a time period from 1998 to 2010. we can see the oscillating trend that follows the upturn in the number of imposed special obligations. Specifically, in 1998 a total of 18 (3.6\%) in 1999. a total of $71(10.6 \%), 2000$ th a total of $176(23.1 \%), 2,001$ th a total of 206 (24.2\%) 2002. a total of 347 (36.2\%) 2003. a total of 267 (32.3\%) 2004. a total of $309(34.1 \%), 2005$. a total of $295(37.1 \%)$, 2006th a total of $332(36.7 \%), 2007 \mathrm{a}$. a total of $305(33.7 \%)$, 2008th a total of $305(34.0 \%)$, 2009th a total of $354(38.3 \%)$ and 2010th a total of 318 (36.7\%) (Kovco Vukadin, 2011., 404).

Considering the state policy of sentencing of special obligations under the qualifying opportunity, we can see that they fully justify their presence in the general register of criminal policies and criminal sanctions that may be imposed on juveniles. On the other hand, the increasing rate of juvenile crime in Croatia, with full respect for the opinions of other authors, further confirms that it is necessary to move in larger steps towards the further development of diversionary measures, both in terms of content, so creating the institutional conditions for their implementation. In this way it is possible to further promote restorative justice based on the idea of reconciliation on both sides (juvenile offender and the victim) with the active participation of the community in the field of their application. 


\section{BASIC CHARACTERISTICS OF DIVERSIONARY MEASURES IN SERBIA}

Finding the most efficient model of reaction to juvenile delinquency is a problem with a lack of an effective response. At a time when the criminal law provisions on the status of minors was part of the general criminal law, applied to dichotomous way of punishing juvenile offenders. There were educational measures and juvenile imprisonment. Corrective measures were major penalties imposed against minors in more than $98 \%$, while the juvenile detention, in accordance with the application of the principles of excellence in punishing older juveniles, uttered in less than $1 \%$ of cases (Statistical Office of the Republic of Serbia, 2012, p. 45). ${ }^{2}$

In Serbia, the last decade made a big step towards a more complete and selfregulating criminal status of minors. Juveniles are distinguished from the general criminal law in particular the Law on Juvenile Offenders and Criminal Protection of Juveniles who enter into force 01 January, 2006. year. In this piece of legislation are the substantive, procedural and enforcement of legislation on minors. The novelty in the regulation of criminal status of minors to introduce a measure of diversion under a separate heading and educational accounts. The reasons for their introduction are primarily of a practical nature and consist in facilitating influence on juvenile offenders measures diversion characters that do not contain repressive elements. This leads to the turning of the criminal proceedings and providing opportunities juvenile offender to improve without the use of measures (sanctions) which contain restrictions and repressive elements (Joksic, 2007, p. 135).

The assumption of "diversion" process implies the existence of two basic conditions: the formal, the law prescribes that possibility and to determine the organs that are responsible to "turn" the ordinary course of the track, and material to determine the new direction, that alternative solutions to their particular facilities and entities that will be applied, implemented and controlled. Fulfilling both conditions may be considered to legislators in addition to regular, traditional procedure, which involves court procedures, promote and affirms the second model in criminal matters, juvenile-diversion model (Radulovic, 2006, p. 225).

In addition to the above the new in juvenile criminal law, educational orders are special measures sui generis which temporarily or permanently suspend the criminal proceedings. They are outside the register of criminal sanctions that may be imposed on juveniles because by their nature, although reminiscent of some corrective measures are based on the principle of voluntariness and reaching an agreement between two parties of a criminal act: the juvenile and the injured party. Legal requirements and conditions for the imposition of corrective orders can be divided into objective and subjective.

2 In Serbia, according to official statistics of the Statistical Office, in 2011th is issued a total of 2290 criminal sanctions for juveniles. At the same time, it is issued a total of 2,277 educational measures and only 13 juvenile prison sentences. 
The objective conditions for the imposition of corrective orders concerning the criminal act, and subjective to the juvenile (Article 5 of the Law on Juvenile Justice). Objective condition for the implementation of corrective orders related to the criminal offense, punishable by a fine or imprisonment for up to five years (paragraph 1). Thus the upper limit prescribed punishments include imprisonment offenses, in the so-called. small and medium-sized crime. However, if we take into account the structure of the minor committed the crimes, we see that the highest percentage of crimes belong to this category.

The subjective requirement that must be done, can be divided into two situations: the recognition of criminal offenses by juveniles and its relation to the offense and the victim (paragraph 3 ). When we talk about recognition of the crime by juveniles, it must be stated: clear, unambiguous, freely and voluntarily, without any conditions, in writing. Such a confession Juvenile Perpetrators may withdraw at any stage of the proceedings, including the period of execution of the order. However, beside the juvenile is necessary that the other party (damaged) agrees to the imposition and implementation of educational order. Another situation involves the relationship of the juvenile crime and the victim. On the perpetration of a criminal offense and the victim must show a repentant attitude accompanied by concrete actions, expressed in his behavior immediately after the commission of the offense and interviewed by the police. This is, above all, to his sincere apology to the injured party, the willingness to compensate for the damage brought things to a time before the execution of the crime, do the number of days specified by the injured party in repairing the consequences of the crime and the like. However, the fulfillment of all legal requirements does not mean that the diversion order be imposed and enforced. In each case, the competent prosecutor or a judge of the juvenile free estimates whether to impose a diversion order (Banovic and Joksic, 2011, pp. 351-352).

The public prosecutor and juvenile judges have at their disposal the ability to impose the following corrective orders (Article 7 of the Law on Juvenile Justice):

1. settlement with the victim to compensation, apology, work, or otherwise remove in whole or in part adverse consequences of a crime,

2. school attendance or regular commute to work,

3. inclusion at no charge to the work of humanitarian organizations and social affairs, local or environmental,

4. submission to the appropriate testing and rehab addiction caused by the use of alcohol or drugs,

5. involvement in individual or group therapy in an appropriate health institution or counseling.

It is evident that the public prosecutor or the juvenile judge has a wide repertoire of corrective orders that may be imposed on a juvenile offender. Thus, the special-prevention plan affects juvenile offender whose actions are not part of the continuing criminal "activity" for more random and its milder form. It is clear that the legislator introducing corrective orders like that when it comes to so-called. 
random or episodic, or crime that has not yet produced serious consequences for society reacts mildest (alternative) measures. Specifically designated purpose of diversion of orders achieved by applying the diversion concept, namely the so-called application. diversion to intervention ("the diversion intervention"). This form is to dispense justice reaction to minors, transferring to the field of health services, nongovermental organisations, social services and so on. (Joksic, 2010, p. 32).

Introducing educative in juvenile criminal law significantly changes the role of the injured party (Jovasevic, 2010, pp. 84-85): she is actively involved in the implementation of certain educative consent to the use of certain educative, and juvenile offender actively involved in repairing the damage caused offense.

Achieving the goals of corrective orders involves the use of psychological methods of personality assessment juvenile offender. Thus certain psychological conditions for the implementation of pedagogic represent only one of a number of conditions that must be met in order to ensure the achievement of prescribed goals. It is interesting that in the case law often leaves a psychological component in the implementation of corrective orders. The reasons lie in the lack of competence of state bodies and institutions involved in the administration and implementation of corrective instructions. The weaknesses can indirectly reflect the weakening effects of corrective orders. We conclude that the effect of educational objectives and must be considered in order correlated. Only in this way can take full advantage of all the benefits brought by the use of corrective orders in criminal law. Therefore, the focus in the implementation of these measures should be special-prevention plan, the broad use of comparative legal experiences (Joksic, 2010, p. 90).

By determining the specific concrete orders, the outcome of criminal proceedings against a juvenile, depending on whether the minor committed corrective instructions. If you do not make a diversion order or complies only in part, but to the extent that justifies further proceedings, the juvenile judge is obliged to inform the public prosecutor for juveniles, who is required to within eight days of receipt of the notification to submit reasoned proposal for the imposition of criminal sanctions. However, if the diversion order fully filled with the juvenile judge shall make a decision on the suspension of the proceedings and notify the victim, who has the right to request the initiation of proceedings (Djurdjic, 2011, p. 419).

A separate issue is the presence of institutional capacity and the capacity of institutions responsible for the implementation of certain educative. This is supported by the fact that seven years after the adoption of the new law did not pass all laws, and educational orders apply only in about $3 \%$ of cases, while in the European Union Member States makes it ten times more. One gets the impression that educational orders formulaic always applied when it comes to primary juvenile offenders of minor crimes. Prosecutors and juvenile judges much more concerned with the objective conditions for their use, and is often a subjective estimate without going deeper into the personality of a minor offender.

The execution of corrective orders including the presence of numerous participants. In addition to the judicial authorities, the juvenile and his parents 
or a representative, this is especially true in the guardianship bodies, educational institutions, healthcare facilities, sports organizations, non-govermental organizations, business organizations and trade associations. Basic assumptions for successful management guidance orders are: clearly define the roles and responsibilities of all participants in the execution of corrective orders; mechanisms of cooperation of the participants and regulators in carrying out corrective orders; defined financing, and the prescribed rules of record keeping. ${ }^{3}$

In judicial practice, however, things are quite different in light of the poor implementation and favoring certain educative. It is evident that educational orders "reluctantly" accepted way of dealing with "criminal conflict" resulting in offenses by juveniles. The weak position of corrective orders is evident in the statistics where most eloquent can not see / ready to be a juvenile, in application of conditional opportunity, protection from stigma and other negative effects of criminal proceedings. Respecting the principle of excellence in punishing juvenile criminal charges end with the imposition of corrective measures as "a major criminal sanctions" aimed at minors. On the other hand, in cases where the imposition and implementation of corrective orders does occur, it usually favors the first on the list of corrective orders' settlement with the victim to compensation, apology, work, or otherwise remove, in whole or in part, adverse consequences of the offense. " In this way disqualify other educational orders in content even though they offer a wide range, to the fulfillment of an obligation, to actively participate in the repair of minors which can result in their specially-preventive effects.

\section{CONCLUDING REMARKS}

New trends in the development of criminal thought also occurred in Croatia, Serbia and other states formed on the territory of former Yugoslavia. Explicit domination punishment as the primary criminal sanctions on adult persons, and corrective measures against juveniles have not contributed to reduced crime rate. On the contrary, with some fluctuations, the crime rate has advanced showing resilience to the challenges of modern times. A large number of authors in both states in his works, has suggested the need to introduce the concept of diversion in the response of society to juvenile crime. In this respect, Croatia in 1997. marked a big step forward by prescribing, in the previous Law on Juvenile Courts, for the imposition of special duties in the implementation of conditional opportunity. Nearly a decade later, the Serbian Law on Juvenile Offenders and Criminal Protection of Juveniles premiere introduced the possibility of imposing diversionary measure called educational orders.

Assumptions, conditions, types and methods of diversion imposing measures in Croatia and Serbia are fully in line with the tendency to assist juvenile delinquents

See Materials of the project: „Improving the implementation of corrective orders "which was prepared by the Republic Institute for Social Protection, Belgrade, p. 11. 
through reconciliation, compensation in the function of fulfilling specific obligations or corrective orders. However, the similarities and differences between the law and the Code of different countries and climates have always existed, they did not interfere with either little importance, because it is a different cultural contexts and value systems. Juvenile criminal law, however, in all climates and cultures has the highest similarity, that is, the least difference to the standardization of the legal and illegal. Types of sanctions and measures, because they're almost identical in all of them dominated by the "conflict" between retributive and restorative approaches. And it should not surprise us, if we compare the differences in these approaches (Nikolic, 2011, p. 362).

Summarizing the above, it is necessary to take into account, both in Croatia and Serbia, to the introduction of new legislation in the light of diversionary measures with adequate social and institutional conditions for their successful implementation. Based on data available implementation of diversionary measures in Croatia and Serbia, but also in other countries in the region, has not met expectations. Reasons related to the lack of financial capacity, institutional framework, human capacity but, in our opinion, and lack of will to take on this plan achieve much more.

\section{LITERATURE:}

Banovic, B. and Joksic, I. (2011). Diversion concept of reaction nan juvenile crime in Serbia: Law and Practice, Teme, 35(2), 345-364.

Caric, A. (2006). The implementation of UN standards for juvenile justice in Croatian juvenile criminal legislation, Split Faculty of Law Journal, 43(1), 1-16.

Caric, A. and Kustura, I. (2010). How's Croatian juvenile criminal law?, Split Faculty of Law Journal, 47(4), 779-820.

Cvjetko, B. (2003). The Croatian project specific duties-court settlement in the earlier proceedings against juvenile and young adult offenders, Croatian Annual of Criminal Law and Practice, 10(1), 49-68.

Cizmek, Z. (2013, January). The aim of the new Law: resocialization of juvenile delinquents. Available at: www.iusinfo.hr/DailyContent/Topical.

Cvjetko, B. (2006). Alternative initiation of criminal proceedings against a juvenile and young adult offenders, and alternatives to criminal procedure in cases of domestic violence, Temida, 9(1), 43-53.

Dimitrijevic, V., Paunovic, M. and Djeric V. (1997). Human Rights. Belgrade: Belgrade Center for Human Rights.

Djurdjic, V. (2011). Discretionary prosecution of juvenile offenders, Teme, 35(2), 403420. 
Jovasevic, D. (2010). Implementation of corrective orders for juvenile delinquents, Social Science Review, 17(1), 77-92.

Joksic, I. (2007). Specificity of alternative measures (educational orders) in the Serbian Criminal Law, Science Security Police, 12(3), 133-143.

Joksic, I. (2010). Corrective recommendations as new measures in Criminal Law. Banja Luka: Faculty of Law.

Koler-Trbovic, N. and Gmaz-Luski, V. (2006). Application of-court settlement (mediation) in pre-trial proceedings against juveniles and young adults, Croatian Annual of Criminal Law and Practice, 13(2), 933-956.

Kovco Vukadin I. (2011). Analysis of the dynamics and structure of crime in the Republic of Croatia in the period between the two major reform of the criminal law (1997 and 2011), Croatian Annual of Criminal Law and Practice, 18(2), 359-416.

Nikolic, Z. and Joksic, I. (2011). Juvenile delinquency (social-psychological and criminal justice aspects). Belgrade: Institute for Criminological and Sociological Research.

Nikolic, Z. (2011). Similarities and differences of juvenile criminal law in Serbia, Croatia, Bosnia and Herzegovina, Montenegro, Foreign legal life, 34(3), 357-364.

Radulovic, Lj. (2006). Diversion orders-alternative sanctions for juvenile development of the legal system of Serbia and harmonization with the EU. Belgrade: Faculty of Law.

Statistical Office of the Republic of Serbia (2012). Juvenile offenders-charges, indictments and convictions for 2011, Bulletin no. 559, Belgrade.

Vidovic, L. (2008). Corporal punishment of children in the family, Croatian Annual of Criminal Law and Practice, 15(1), 303-320. 


\section{DIVERZIONE MERE KAO NOVI ODGOVOR DRUŠTVA NA KRIMINALITET MALOLETNIKA U HRVATSKOJ I SRBIJI}

U svakom društvu postoje pojedinci ili organizovane grupe koje otvoreno ili prikriveno krše društvene norme kojima se unapred propisuju obrasci ponašanja. Opasnost od ovakvih postupaka ogleda se u prisustvu negativnih tendencija na polju dalje društvene dezorganizacije. Poznato je da se neretko za kriminalitet maloletnika sazna tek onda kada je neophodno primeniti represivnije sankcije koje sadrže brojna ograničenja. S obzirom na činjenicu da je kazna dominirala kao krivična sankcija reakcija društva na kriminalitet mladih bila je isključivo punitivnog karaktera. Otuda se na maloletnike primenjuju istovrsne kazne uz određena ograničenja koja se tiču blažeg kažnjavanja i znatno liberalnijeg režima izvršenja kazne zatvora.

U takvoj situaciji društvo nije ostvarilo ozbiljniji uticaj na poboljšanje statusa maloletnika i njihovu punu integraciju u svoje tokove. Dalji razvoj društvene i pravne svesti uticao je na pronalaženje novih formi ne/penalnog reagovanja. U tom pogledu, diverzione mere predstavljaju prvi i pravi korak na putu popravljanja maloletnih delinkvenata za konkretno učinjena krivična dela uz ispunjenje određenih uslova. U sklopu opštih tendencija usaglašavanja unutrašnjeg sa uporednim zakonodavstvom i međunarodnim i regionalnim, pretežno evropskim instrumentima, države ex Jugoslavije ugradile su u svoja zakonodavstva mogućnost izricanja diverzionih mera. Vodeći računa o planiranom obimu rada autori su odabrali Hrvatsku i Srbiju koje su svaka na svoj način, najpre propisale, a onda uz velike poteškoće otpočele sa sporadičnom primenom diverzionih mera.

Ključne reči: društvo, maloletnici, diverzione mere, reintegracija, tretman, poravnanje sa oštećenim 